\title{
The use of Short Animated stories to improve students' writing in Narrative text at SMP N 3 Natar \\ Tri Agustin ${ }^{1}$, Cucu Sutarsyah ${ }^{2}$, Huzairin ${ }^{3}$ \\ UniversitasLampung,Jl.Prof. Dr. Sumantri Brojonegoro,Rajabasa, Bandarlampung ${ }^{1,2,3}$ \\ ${ }^{1}$ Correspondence:agustintri14@gmail.com
}

\begin{abstract}
S
This study aimed to find out whether there is a significant difference in students writing narrative text after being taught through using short animated stories and to find out which aspect of writing skill that improves after being taught by using short animated stories and to investigate what is the student's response after being taught through using short animated stories. The sample of this research was VIII B at SMP N 3 Natar. The writing test and questionnaire were administered as the instrument of this research. The data were analyzed by using a repeated measure t-test in which the significance was determined by $p<0,005$. The result showed that the students' mean score in the pretest 52.26 while in the posttest mean score was 64.17 in which tvalue $>t$-table $(27.814>2.074)$ or sig $p<0.05(0.000<0.05)$. Furthermore, organization $(3.41)$ was the aspect of writing that was improved by students. Besides, the result of questionnaires showed that most students (78.3\%) gave positive responses toward the implementation of short animated stories in writing narrative text. Thus, it can be concluded that Short Animated Stories is effective to improve students writing narrative text.
\end{abstract}

\section{Keywords: Short Animated Stories, Writing Skill, Narrative text}

\section{INTRODUCTION}

English is acknowledged as a necessary language to enable the Indonesian community to involve in global communication, it is taught even from elementary school. English is not our native language, as a fact that mastery it is not easy. There are four skills in learning English, namely speaking, reading, listening, and writing. Writing is one of the language skills that are important to be improved in academic life. As stated by Harmer (2004) that, "Writing (as one of the four skills of listening, speaking, reading, and writing) has always formed part of the syllabus in the teaching of English". It means that English is a part of language education. Through writing, students can express their feeling, process information, and learn actively.

Writing is a form of communication that allows students to put their feelings and ideas on paper, organize their knowledge and beliefs into convincing arguments, and convey meaning through well-constructed text. Sudaryanto (2001) says that writing skill is a person's ability to express his/her mind and feeling which is expressed in a written language, in graphic symbols so that the readers can understand the message inside. In writing, students have to know about grammar, vocabulary, sentence structure, punctuation, and spelling. In expressing the thought into a written language, feeling plays an important role as well, so that the products will be easily understood and enjoyed by the readers. Therefore, writing skills need to be taught to the student.

Based on the pre-research at SMP N 3 Natar, it was found that many students have difficulties in learning to write narrative text. They came from students and teacher's factors. Firstly, students do not have enough practice in writing text because many students have difficulty starting to write and put their idea into writing especially in a narrative text. Therefore, the students need to master the structure of the English language, vocabulary, and also know the spelling of the words to be 
able to write correct sentences. Second, students think writing is a very difficult thing. This is in line with Taylor (2009) support by saying that for most people writing is an extremely difficult task if they are trying to grab in their language with new ideas and new ways of looking at them. Besides, Harmer (2007) said that mastering productive skills especially writing can be very stressful if they do not know the appropriate words or grammar to express the idea. So, they did not how to start writing their experience or idea into good writing. The last problem is low motivation. The boring teaching techniques and classroom atmosphere do not support the students' motivation to write a paragraph. Therefore, students need the motivation to overcome their difficulties in writing.

Based on the facts above, the teacher needed variations in teaching writing in a narrative text to motivate their students because the students don't have motivation in learning writing. The teacher had to find the media to make students motivated to build their self-confidence in writing. Some media could be picture series, comics, movies, and animated stories. In teaching narrative text, short animated stories are better to be used as media. Short animated stories are more interesting than picture series or comics because they are moving pictures, so students will see the actions of characters. The duration of the film is about 7 to 10 minutes, therefore it will help the teacher in managing time for teaching. Harison and Hummell (2010) say that animated stories can enrich the experience and competence of the students in a variety of teaching materials. Through a variety of methods, teachers and students can use the animation of the most simple to present several concepts. Animation has an advantage that can help in establishing students' understanding of materials. One of the writing forms that should be made by students is narrative text. The narrative text refers to a text which tells a story to entertain the reader. Anderson and Anderson (1997) say that narrative text is a piece of text which tells a story and in doing so entertains and informs the reader or listener. Meanwhile, Percy in Permana and Zuhri (2013) say that narrative is a type of essay that tells a story or a series of events in which they occur. Its purpose is to give meaning to an event or a series of events by telling a story. The story includes some events which are presented to amuse the readers or listeners. So, written narrative texts are aimed to entertain the readers.

Through watching short animated stories, students can catch the idea of the setting, plot, and the important thing is the moral value. Therefore, the students can make their own stories based on their imagination after watching the movie. Besides, the researcher was interested to use this media which aimed at finding out a significant difference before and after the implementation of short animated stories and to find out which aspect of writing that improves by students after being taught by using short animated stories and to investigate what is students response after being taught using short animated stories.

\section{METHODS}

This research used a quantitative approach by using one group pre-test post-test design. The quantitative method is method deals with statistical analysis data in the form of scores and numbers (Creswell, 2012). The population for this research is the students in the second grade of SMP N 3 Natar. In the sample of this research, the researcher chooses 30 students from VIII B by using purposive sampling. The data are collected by using tests (pre-test and post-test) and questionnaires. Then, the improvement of students' test results is analyzed by using Repeated 
Measured T-Test to find out whether any significant difference in students' writing in the narrative text after the implementation of short animated stories.

\section{RESULTS AND DISCUSSION}

After conducting the research, the researcher gathers the result of the pre-test and post-test as

Follow:

\section{Result}

Table 1. The Students' Mean Score in Pre-test and

Posttest Descriptive Statistics

\begin{tabular}{llllll}
\hline & $\mathrm{N}$ & Minimum & Maximum & Mean & Std. Deviation \\
\hline PRETEST & 23 & 40.50 & 66.00 & 52.2609 & 8.32011 \\
POSTTEST & 23 & 51.50 & 78.50 & 64.1739 & 9.18201 \\
& & & & & \\
\hline Valid N (listwise) & 23 & & & & \\
\hline
\end{tabular}

Based on the table 1, it could be seen that the minimum score of pretest was 40.50 and the minimum score of post test was 51.50. The increase of the minimum score was 11 . The maximum score in pretest was 66.00 and the maximum score in post test was 78.50. The increase of the maximum score was 12.5. The mean score of the pre test was 52.26 and the posttest was 64.17. The increase of the mean score was 11.91 .

Table 2. Result of Paired Sample T-test

Paired Samples Test

\begin{tabular}{|c|c|c|c|c|c|c|c|c|}
\hline & \multicolumn{5}{|c|}{ Paired Differences } & \multirow[b]{4}{*}{$\mathrm{T}$} & \multirow[b]{4}{*}{$\mathrm{df}$} & \multirow{4}{*}{$\begin{array}{l}\text { Sig. (2- } \\
\text { tailed) }\end{array}$} \\
\hline & \multirow[b]{3}{*}{ Mean } & \multirow{3}{*}{$\begin{array}{l}\text { Std. } \\
\text { Deviation }\end{array}$} & \multirow{3}{*}{$\begin{array}{l}\text { Std. Error } \\
\text { Mean }\end{array}$} & \multirow{2}{*}{\multicolumn{2}{|c|}{$\begin{array}{l}95 \% \text { Confidence } \\
\text { Interval of the } \\
\text { Difference }\end{array}$}} & & & \\
\hline & & & & & & & & \\
\hline & & & & Lower & Upper & & & \\
\hline $\begin{array}{r}\text { Pair } 1 \text { PRETEST - } \\
\text { POSTTEST }\end{array}$ & $-11,91304$ & 2,05411 & ,42831 & $-12,80131$ & $-11,02478$ & 27,814 & 22 &, 000 \\
\hline
\end{tabular}

The table shows that the t-value is 27.814 with a degree of freedom (df) is 22 . While the data significant based on the t-table points out at 2074. Thus, it can be concluded that the t-table $(27.814$

$>2074$ ) with the significant level is $5 \%$ or 0,05 . From the result above, the null hypothesis is rejected and $\mathrm{H} 1$ is accepted (H1 there is a significant difference in students' writing skills after the implementation of short animated stories. The table also reveals the increase of the pre-test and post-test is 11.91 .

To answer the research question of which aspect of writing that improves by students after being taught by using short animated stories, the researcher was analyzed the students writing test in pre-test and post-test by comparing their writing to find out the aspect of writing that improved by 
the students after the implementation of short animated stories. The data of the result of students writing would explain which aspect of writing that improved by the students.

Table 3. Result of the Improvement of Each Aspect in Writing Skill

\begin{tabular}{lccccc}
\hline $\begin{array}{l}\text { Aspect } \\
\text { Writing }\end{array}$ & of Percentage(\%) & $\begin{array}{l}\text { Mean of Pre } \\
\text { Test }\end{array}$ & $\begin{array}{l}\text { Mean of Post } \\
\text { Test }\end{array}$ & Gain & $\begin{array}{c}\text { The } \\
\text { Improvement }\end{array}$ \\
\hline Content & $30 \%$ & 16.82 & 19.10 & 2.28 & $19.09 \%$ \\
Organization & $20 \%$ & 11.60 & 15.01 & 3.41 & $28.55 \%$ \\
Vocabulary & $20 \%$ & 10.64 & 13.88 & 3.24 & $27.13 \%$ \\
Language Use & $25 \%$ & 10.54 & 13.14 & 2.6 & $21.77 \%$ \\
Mechanic & $5 \%$ & 2.47 & 2.88 & 0.41 & $3.43 \%$ \\
\hline Total & $100 \%$ & 52.07 & 64.01 & 11.94 & $99.97 \%$ \\
\hline
\end{tabular}

Based on the table, it can be seen that there is an increase in each aspect of writing after using short animated stories. It also could be seen that the gain of content is 2.28 , the gain of an organization is 3.41 , the gain of vocabulary is 3.24 , the gain of language use is 2.6 , and the gain of mechanic is 0.41 . It means that the organization improved the most than other aspects. In short, short animated stories could improve the students' writing skills in all aspects of writing.

To answer the third research question, that is students' response after being taught through using short animated stories. The researcher was analysis the students' questionnaire to investigate the students' responses to the use of short animated stories in teaching writing. The researcher classified the students into two categories: negative and positive.

Table 4. Students' Respond of Short Animated

Stories Students Respond of Short Animated Stories

\begin{tabular}{lllll} 
& Frequency & Percent & Valid Percent & Cumulative Percent \\
\hline NEGATIVE & 5 & 21,7 & 21,7 & 21,7 \\
& & & & 100,0 \\
POSITIVE & 18 & 78,3 & 78,3 & \\
Total & 23 & 100,0 & 100,0 & \\
\hline
\end{tabular}

The table above shows that there are students $(21.7 \%)$ who gave a negative response and most students $(78.3 \%)$ gave a positive response toward the implementation of short animated stories in writing narrative text. The number of students who gave positive responses to short animated stories is more than they who have a negative responses. It means the students gave positive responses toward the use of animated stories in learning writing.

\section{Discussions}

Referring to the research question on the research, the researcher would like to find out whether there is a significant difference in students writing narrative text after using short animated stories 
and which aspect of writing skill that improves by students after being taught by having short animated stories and what is the student's response after being taught through using short animated stories.

While conducting the research, in the first meeting or pre-test, the researcher found some problems with student's writing skills in narrative text. They lacked in each aspect of writing skills consequently the students' difficulty to express their ideas into sentences, they did not know how to start writing their ideas, and also they were lack of motivation to learn writing. So, the researcher took action to overcome that problem by teaching writing skills through short animated stories.

At the time of data collection, the researcher carried out two situations in teaching, namely normal situations, and online situations. This is due to the Covid 19 pandemic. This situation causes researchers to have long-distance or online learning. In taking data, the researcher taught narrative

text by using short animated stories in 3 meetings. The first meeting occurred before the Covid 19 pandemic which was called a normal situation. Meanwhile, in online situations, namely at the second and third meetings, until the provision of post-tests and questionnaires.

The first hypothesis was answered that there was a significant difference in students' writing narrative text after the researcher conducted the treatment. It can be seen from the mean score between pretest and posttest where the difference is 11.91 (from 52.26 to 64.17). The mean score of the pretest is 52.26, to find out the students writing narrative text before the treatment, the researcher administered the pretest before implementing short animated stories in learning writing. Meanwhile, the mean score for the posttest is 64.17. Then the result was analyzed by using the Repeated Measures T-Test, it was also found that the t-value was higher than the t-table and a significant level was achieved. Therefore, it was confirmed that there was a significant difference in students' writing narrative text after the students were taught by using short animated stories in learning writing.

In this study, the researcher also analyzed aspect of writing that improves by students after being taught by using short animated stories. After the researcher analyzed the posttest have been done by the students, the researcher found that organization improved the most than other aspects. Furthermore, the researcher analyzed the result of a questionnaire by students after being taught by using short animated stories. The result shows that most of the students $(78.3 \%)$ had positive responses toward the use of short animated stories in learning writing.

Overall, by using short animated stories the students' ability in writing narrative text improves. It could be seen in the posttest of students was better than before. When the researcher applied short animated stories the students feel enjoy, interest, and motivate the students because the movie can help in establishing students' understanding of materials and help the students to get their idea easily so that students can express their ideas in writing. Lavery (2008) argues that film and video are effective ways in motivating and helping students to understand the language. Short animated stories can be used to teach all aspects of writing such as grammar and vocabulary because the film provides the language or subtitle. The students can learn from the dialogue or subtitle films' can help to reinforce the acquisition of new vocabulary. Wright (1976) that short animated stories 
or animation films or videos contain some elements of narrative such as characters, dialogues, plots, and climax. Therefore, students could understand easier in learning the writing aspect (content, grammar, vocabulary, organization, and mechanics) and write narrative text because short animated stories provide some elements of generic structure and language feature of narrative text. Students can learn the aspect of writing through short animated stories because it shows real images and simple stories and provides the dialogue that can be used to learn grammar and vocabulary aspect. It also proved by Sherman (2003) video can stimulate and motivate students' interest. While learning the language, the students could get the visual context provided by the pictures in the video which portray the situation, environment, gestures, and other visual clues which can help students to understand the message. Students will be encouraged to imitate what they see or hear and animated video provides both of them to make their learning more interesting which leads students to be more active in classroom participation.

Referring to the explanation above, the students can encourage their writing and motivate them in learning writing by using short animated stories. They were easy to write what they want without a particular topic, they could express and develop their idea. Besides, it can be inferred that short animated stories are good media in teaching writing to improve student's narrative writing skills.

\section{CONCLUSIONS AND SUGGESTIONS \\ Conclusions}

Based on the data analysis and discussion of the research findings, the researcher comes to the following conclusions. There was a significant difference in students' writing skills in a narrative text after being taught through using short animated stories which could be seen from the gain of students' writing mean score in pre-test and post-test ( from 52.26 to 64.17). So, it can be concluded that the treatments using short animated stories was more helpful to improve writing skill.

Short animated stories gave an improvement to all aspects of writing. After analyzing the data, the result shows that the aspect of writing that improved the most is Organization. It can be seen from the gain score of Organization is 3.41. It can be concluded that the aspect that improved after the implementation of short animated stories is Organization since it helps the students to write their ideas in a text well. Furthermore, all students had a different response after the use of short animated stories. Out of 23 students, 18 students (78.3\%) had a positive response and 5 students (21.7\%) had a negative response. The students' response about the use of short animated stories in-class activity was positive.

\section{Suggestions}

Referring to the conclusion above the researcher would like to recommend some suggestions as follows: the researcher suggest for the English teacher to apply short animated stories as one of the media to increase the students' writing narrative text because short animated stories can help the students in expressing their idea into sentences. And also, the researcher suggests to other future research, can try in different levels of schools. And also this research was aimed to help students for improving their writing skills through short animated stories. Therefore, the researcher suggested for the other researcher who wants to conduct similar research can use the media of this research as a reference. 


\section{REFERENCES}

Anderson, M., \& Anderson, K. (1997). Text types in English 2. South Yarra: Macmillan Education Australia PIY Ltd.

Creswell, J.W. (2012). Research design quantitative approach and mixed. Yogyakarta: Pustaka Pelajar.

Harmer, J. (2004). How to teach writing. London: Pearson Education Limited.

Harmer, J. (2007). The practice of English language teaching. Harlow: Longman.

Harrison, H. L., \& Hummell, L. J. (2010). Incorporating animation concepts and principles in STEM education. Technology Teacher. USA. (69), 20-25.

Lavery. (2008). Activities for using comics strips. Retrieved from www.TeachingEnglish.org.Uk.

Permana, T. D., \& Zuhri, F. (2013). The implementation of picture series as media in teaching writing of a narrative text of the tenth graders of Senior High School. Unpublished S1 Thesis. State University of Surabaya.

Sudaryanto. (2001). Peningkatan keterampilan menyusun wacana narasi melalui penerapan pendekatan ekletik. Cakrawala Pendidikan. (1), 61-69.

Sherman, J. (2003). Using authentic video in the language classroom. Cambridge: Cambridge University Press.

Taylor, G. (2009). A student's writing guide. New York: Cambridge University Press.

Wright, A. (1976). Visual materials for the language teachers. London: Longman Group Ltd. 